\title{
Case Selection in Comparative Law Based on Hofstede's Cultural Psychology Theory
}

\author{
Special Issue - Comparative Law
}

Dave van Toor*

'Comparative law is a 'strange animal"

Siems 2014, p. 9

\section{Introduction: Undertheorized Case Selection in Comparative Research}

According to the empirical study performed by Van Boom \& Van Gestel 61 per cent of the 572 interviewed Dutch legal scholars conducts comparative legal research (van Boom \& van Gestel 2015, p. 1344). These numbers would suggest that comparative methodology, including case selection criteria, should hold a prominent place in the comparative literature (if the Dutch survey is representative worldwide). However, "the "comparative" aspect of the enterprise, as a method and a project, remains undertheorized and blurry' (Hirschl 2014, p. 3). One of the most difficult and controversial points of legal comparative methodology is the selection of cases (Hirschl 2005, p. 125; also Palmer 2005, pp. 261-290), but the discussion in the literature also points out the lack of debate about methodology in general (Hirschl 2014; Siems 2014, p. 33). Criteria such as proximity, language and legal tradition (e.g., common law versus civil law, Napoleonic criminal law versus German criminal law) are regularly used to select cases, and with good cause. The first two criteria can be relevant as an 'exclusionary rule', because comparing countries without understanding the language, even in the age of Google Translate, or without access to a country, is unworkable. The third criterion is a broad and general selection criterion to categorize countries.

However, the three above-mentioned criteria have disadvantages. The first two (practical) criteria are in no way relevant for the working mechanisms of the countries' law, and can therefore not be used as theoretical (and independent) variables in explaining differences between countries. ${ }^{1}$ The third criterion is too broad and provides a Euro-centred selection bias. How can one choose between the several countries with a common law tradition and civil law tradition when

* D.A.G. van Toor, PhD LLM BSc works as a researcher and lecturer in Criminal (Procedural) Law and Criminology at the Universität Bielefeld.

1 See Hage 2014, pp. 2-4 about inference rules in conclusions. 
comparing, for example, the working and the criteria of self-defence in criminal law? The 'usual suspects' are mainly included in comparative research and tend to be overanalysed, where the Nordic countries, sub-Saharan Africa and Central and South East Asia remain largely uncharted terrain (Hirschl 2014, p. 4; Hirschl 2011, p. 452). ${ }^{2}$ Furthermore, the legal system has impact on the working of the chosen country's law and its elements as well (Siems 2014, p. 16), ${ }^{3}$ and is therefore in no way independent (which excludes causality claims (Hirschl 2005, p. 126, 131)).

It is therefore important that, '[e]ven when one's knowledge of languages will be the prime reason for choosing or eliminating some country, the researcher should be able to give good reasons why her choice is acceptable from a scholarly point of view' (van Hoecke 2015, p. 4). According to Hirschl, it is necessary to pay more attention to inference-oriented principles of research design and case selection to allow causal claims (Hirschl 2014, pp. 5, 228; Hirschl 2005, p. 154). ${ }^{4}$ A call, in short, for 'methodological pluralism' and the use of interdisciplinary research designs in comparative legal research (Hirschl 2014, p. 280; Young 2016, p. 1376; Law \& Versteeg 2011, p. 1248). However, theories about selection criteria remain absent.

Hirschl theoretical selection principles offers several research design to be used in comparative law: they include the most similar case, the most different case, the critical case, the prototypical case, the most difficult case and/or the outlier case (Hirschl 2005, pp. 132-152). However, these principles also have a disadvantage: they "only" provide a design, and do not provide a subsequent theory or theories how to select cases. A researcher who wants to use one of the proposed designs still has to develop selection criteria.

The large- $\mathrm{N}$ method can be a solution for the unwanted influence of heuristics and biases (Hirschl 2014, p. 267). But a large-N method is time-consuming and costly, and unpractical due to problems relating to the language, accessibility and availability. ${ }^{5}$ In light of these criticisms on the case selection in general and the large- $\mathrm{N}$ method, there is still a lot to be said about case selection in comparative legal research, especially about case selection theories.

It is my (first) hypothesis that the cultural-psychological theory of Hofstede and colleagues (Hofstede 1980; Hofstede 1984; Hofstede 1997; Hofstede \& Hofstede 2005; Hofstede et al. 2011; Hofstede et al. 2002) provides a solid base for case selection in comparative (quantitative and qualitative) research. My (second) hypothesis

2 However, this trend is changing. Cambridge University Press with an Asian Journal of Comparative Law, which now covers eleven volumes since 2006. See also, Kitagawa 2006; Dixon \& Ginsburg 2014.

3 A. Huxley, 'Review of 'The Golden Yoke: The Legal Cosmology of Buddhist Tibet by Rebecca Redwood French; Law and Morality in Ancient China: The Silk Manuscripts of Huang-Lao by R. P. Peerenboom", The Yale Law Journal, 1997 (106), 6, p. 1924-1925.

4 Also Jackson 2016, p. 1360. Partly supporting Meuwese 2006.

5 It is no wonder that Hirschl (2016: 1422) sees linguistic talent as a valuable factor for a (successful) comparatist. 
is that differences in cultural-psychological dimensions of countries can help explain legal differences, and gives insight on the relationship between law and culture. Hofstede's dimensions are used to differentiate between nations' culture on six different topics, for example whether a country values individual performance above group performance as part of the individualism-collectivism index. These dimensions are objective and strongly supported, reproduced and refined by decades of empirical research. To test hypotheses about whether and why different laws are enacted or how concepts are defined in distinctive cultures, case selection for comparative legal research should be based on the cultural-psychological dimensions (cf. the independent variable in experimental research). These criteria help researchers select culturally similar and dissimilar cases, in which (hypothesized) legal differences can be examined. ${ }^{6}$ Hofstede's criteria are not meant to make other selection criteria redundant, but to select (dis)similar cultures for comparison.

In this article, I will introduce an interdisciplinary case selection criteria theory on the basis of cultural-psychological research. In Section 2, the necessity of interdisciplinary case selection will be argued, at least for research regarding the working of the law in context, but not for the comparative research goals (i) identifying alternative possibilities and (ii) a critical perspective on national law. The cultural-psychological dimensions of Hofstede and colleagues are introduced in Section 3. The same section will also include research possibilities using Hofstede's dimensions in comparative law. Section 3.3 will give a more in-depth analysis of cultural-psychological case selection to analyse the concept of privacy and privacy laws across the globe, to discover whether a universal core of privacy protection can be found across cultures.

\section{Interdisciplinary Case Selection: The Use of Cultural-Psychological Dimensions}

Siems proposes that comparative law has three dimensions: (1) the areas of law (such as constitutional law and criminal law); (2) legal regimes (such as German, French and Common); and (3) methods (inter alia economics and culture) (Siems 2014, p. 8). If these three 'cornerstones' are always used in comparative research, the research would be necessarily interdisciplinary. But according to Siems, most lawyers are only interested in the connection between the areas of law and legal regimes. Using cultural dimensions as case selection criteria will kill two birds with one stone.

First, the third cornerstone is part of the comparative research when cultural-psychological dimensions are used, because the case selection is based on cultural differences between nations. Second, case selection on the basis of

6 Comparative research with a cultural case selection will also be a valuable extension on Hofstede's theory, and can maybe even falsify some aspects. For example, what if comparable cultures have different laws? 
cultural-psychological dimensions allows researchers to make causal claims. These selection criteria make it possible to select countries with different scores on distinctive cultural-psychological dimensions, with which the legal scholar can assess whether the selected countries enacted different laws in perspective of the selection criteria. My hypothesis is that differences in cultural-psychological dimensions of countries can help explain legal differences. Siems already saw the value of Hofstede's research on cultural psychology (Siems 2014, pp. 21, 309-311), but only as a factor to include in explaining legal differences. This, however, can still leave problems for making causal claims because the case selection was based on irrelevant and/or biased criteria. To profit in full from Hofstede's research, comparative researchers should formulate hypotheses about the influence of cultural-psychological dimensions on laws and legal systems, so that causal claims can be made.

In this way, the comparative research will use cultural differences between countries to (1) formulate hypotheses about legal differences - such as that the meaning of the right to respect for privacy is dependent on a nation's score on the individualism index (IDV); (2) select cases on the basis of the cultural-psychological dimensions, which act as independent variables in experimental research - for example, two countries with a high score on IDV, two with a moderate score and two with a low score; and (3) explain legal differences (cf. Siems 2014, pp. 21, 309311). If, for example, privacy laws in the United States of America promote autonomous life decisions (privacy-as-autonomy) and protect against unwarranted intrusion (privacy-as-secrecy), whereas in Guatemala only privacy-as-secrecy is constitutionally protected, one can argue that a nation's individualism is or can be a factor to influence the legal concept of privacy and the protected aspects of privacy.

Further advantages of Hofstede's dimensions as case selection criteria is that Hofstede's data is available online, ${ }^{7}$ which allows - after a hypothesis is formulated and cultural-psychological dimensions as selection criteria are set - fast and cheap case selection that can objectively be justified. Hofstede's dimensions are objective, strongly supported, reproduced and refined by decades of empirical research and are therefore independent selection criteria. And, as Hage highlights, good hypotheses are essential fuel for the process of generating academic development (Hage 2014, p. 11).

Before I describe Hofstede's dimensions in more depth, I will add two remarks to my hypotheses. Although using cultural-psychological dimensions as variables for case selection offers sound and independent options, it is not the holy grail of comparative methodology. First and foremost, comparative scholars should formulate a research question and, depending on that question, determine selection criteria. If the goal of comparative research is formulating alternative rules because the national rules are not functioning properly (according to the courts, lawmak-

7 The list includes 102 countries at the moment. See https://geert-hofstede.com/countries.html, last retrieved on 26 January 2017. 
ers or practitioners), the use of cultural-psychological dimensions to make causal claims is unnecessary. The same holds true for comparative research that allows a deeper understanding and/or a critical perspective of one's own law.

When the goal of the comparative project is explaining why differences between countries' laws or between legal systems occur, the use of independent case selection criteria is essential. For example, Blok's goal in his doctoral research was 'to bring order to the chaos regarding the meaning of the term "privacy"' (my translation) (Blok 2002, p. 2). This research is eminently suitable for case selection based on cultural-psychological dimensions, because different cultures will have a variety of privacy laws and the privacy concept will be influenced by cultural preferences. This kind of research - with a broad research question regarding the law in context that does not already confine case selection - will profit the most of interdisciplinary designs, and especially interdisciplinary case selection criteria. Below, I will describe the cultural-psychological dimensions of Hofstede's theory. Hofstede (and colleagues, most prominent are Hofstede (his son) and Minkov) identified the following dimensions on which cultures differ: (1) power distance, (2) individualism versus collectivism, (3) masculinity versus femininity, (4) uncertainty avoidance, (5) long-term versus short-term orientation and, (6) indulgence versus restraint (Hofstede 1980; Hofstede 1984; Hofstede 1997; Hofstede \& Hofstede 2005; Hofstede et al. 2011; Hofstede et al. 2002).

\section{Hofstede's Cultural-Psychological Research as Basis for Case Selection in Comparative Law}

Starting in the 1960s, Hofstede used an attitude survey ${ }^{8}$ to gather information about employee values in a large multinational: IBM. The survey was conducted at IBM locations in 72 countries, and includes an astonishing 116,000+ respondents. In order to confirm the early results from the IBM study and to extend them to a variety of populations, six subsequent cross-national studies have successfully been conducted and the database is still growing. The factor analysis of the databank led Hofstede to conclude that cultures differ on four dimensions (for example, Hofstede 2001, p. 351). In 1991 he added a fifth dimension (long-term versus short-term orientation), and new analysis of the data by Minkov led to the inclusion of a sixth dimension (indulgence versus restraint) (Hofstede et al. 2010).

Hofstede used these dimensions to determine a country's culture by giving each country on each dimension a score between 0 and 100. Although the last two dimensions did not receive the same universal acclaim as the first four (Fang 2003, pp. 347-368), ${ }^{9}$ the theory proved to be one of the most robust psychological

8 The questionnaires of 2008 and 2013 can be downloaded for Hofstede's personal website: http:// geerthofstede.com/. This website also contains data of the countries included in the survey.

9 General criticism: Ailon 2008, pp. 885-904; Baskerville 2003, pp. 1-14; McSweeney 2008, pp. 89-117. 
theories of the last century (Kirkman et al. 2006, pp. 285-320; Wu 2016, pp. 33-42). It is not my intention to discuss the theory and criticism in-depth. It suffices to acknowledge that the theory is robust, but also criticized. My hypothesis is that the dimensions are a valuable tool for case selection in comparative research, and have a threefold advantage with respect to 'traditional' criteria: the dimensions can be used to (1) formulate hypotheses about legal differences; (2) select cases on the basis of the cultural-psychological dimensions, which act as independent variables in experimental research; and then (3) to explain legal differences. Hofstede's dimensions will be explained briefly in Section 3.1. ${ }^{10}$ Section 3.2 consists of examples relating the cultural dimensions to laws or aspects of legal systems. The already mentioned example of the relationship between the concept of privacy and privacy laws with respect to the score on individualism will be explored in more detail in Section 3.3.

\subsection{Hofstede's Dimensions}

The first dimension analysed from the IBM survey is named power distance. This dimension relates to how society handles the extent to which people accept power distribution. A high power-distance society believes in strict authority and hierarchy and has low egalitarianism. Inequality can take many forms, namely in social status and prestige (for example, the class system in India), wealth, education, and unequal rights for different groups. Less 'powerful' citizens of such societies tend to accept this unequal power distribution. A low power-distance society emphasizes egalitarianism and shared power. The leader in such a society is a primus inter pares.

The second dimension has been labelled uncertainty avoidance. People in different societies tend to vary on how they handle the inherent uncertainty about the future. Coping with uncertainty belongs to the cultural heritage of societies. Cultures with high uncertainty avoidance value order, structure and predictability, and tend to value the authority of rules and laws highly. Citizens from high uncertainty avoidance cultures have a tendency to have low tolerance for conflict and value security over risk. In contrast, in cultures with low uncertainty avoidance risk-tasking, limited structure and ambiguity are the norm.

The third dimension is called individualism (versus collectivism). This dimension describes the value that is placed on the individual or the collectivity in societies. For example, how people live - single apartments, together with extended family members, in a kibbutz - and the degree to which people prefer to act as individuals rather than as members of groups are reflections of the society's individualism or collectivism. In cultures that score high on individualism, the needs of individuals are accentuated. Individual achievements are highlighted, and so are standing out and being unique. The opposite is true for collectivistic cultures, where group successes have more impact than individual achievements. Willingness to 
support the group and larger societal goals are more important than individual pursuits.

The fourth dimension along which cultures differ has been called masculinity (versus femininity). The main issue regarding this dimension in cultures is what implications gender differences should have for the role of the genders in society. In higher masculine countries, values like assertiveness, performance, success and competition - which are seen as prototypical masculine values - prevail over values like quality of life, maintaining warm personal relationships, service, care for the weak, and solidarity - which are seen as prototypical feminine values.

The fifth dimension was added in the 1990s and describes the difference between a culture's long-term and short-term orientation. This dimension addresses the different ways cultures view time and the importance of the past, present and the future. It describes cultures on the degree to which people are focused on the future, as opposed to the present and past. People in long-term-oriented cultures value persistence, perseverance, saving and being able to adapt. People in shortterm-oriented cultures value tradition, the current social hierarchy and fulfilling social obligations.

The sixth and last dimension was added in 2010 and is called indulgence (versus restraint). A society that practices indulgence makes room for the comparatively free gratification of natural and basic human drives pertaining to indulging in fun and enjoying life. The quality of restraint describes a society that holds back need on gratification and tries to control it through stringent social norms.

\subsection{The Use of Hofstede's Dimensions as Selection Criteria: Some Examples}

The main point of using Hofstede's cultural-psychological dimensions as case selection criteria is that they can function in the way independent variables function in experimental research. As mentioned before, hypotheses about legal differences should be formulated using cultural-psychological dimensions, after which the same dimensions are used to select cases. When legal differences are found in the selected countries, the cultural-psychological selection criteria can be used in explaining why differences occur in the selected countries. This use of Hofstede's dimensions is a step in the direction of 'culturalism' in comparative legal research (Di Robilant 2016, p. 1326), but without the necessity of knowing a country's culture beforehand. The scores on Hofstede's dimensions are easy and freely accessible on the internet and include over 100 countries. Additionally, they are objective and verifiable because they are based on a large body of research, done over decades.

For example, according to Siems England, Scotland and the Netherlands may be regarded as similar from a sociological perspective, and it is therefore interesting to investigate why their judicial systems and laws are so dissimilar (Siems 2014, p. 124). In order to assess the differences in law systems, hypotheses can be based on the cultural differences between the Netherlands and the United Kingdom (in Hofstede's databank England, Scotland, Wales and Northern-Ireland are combined). Based on the dissimilarities, a hypothesis could be that a country with a system that has a stronger focus on written laws should have a higher score on 
the uncertainty avoidance index because written laws provide more structure and order. A second hypothesis could be that cultures with written laws tend to have higher long-term orientation because written laws tend to regulate future behaviour more clearly. As can be seen in Figure 1, both cultures score (more or less) equal on power distance, individualism and indulgence. The largest differences occur on masculinity, and smaller differences on uncertainty avoidance and longterm orientation. To assess the connections, on the one hand, between uncertainty avoidance and long-term orientation and, on the other hand, between civil law and common law systems and their use of written laws, more cultures with different systems should be included (or the scores of a culture from the 1970s until today could be compared, to assess whether the changes in the society's uncertainty avoidance had any influence on the use and numbers of written laws). ${ }^{11}$

As a further example, the power distance dimension - this dimension relates to all sorts of inequalities within a culture, including the relationship between authorities and civilians - can be used to select countries for comparative research on a lot of topics. For example, power distances scores are related to the process of democratization (Wu 2016, pp. 33-42) and can therefore be used to assess differences in political systems and voting rights. In addition, it can be hypothesized that a culture's power distance has influence on aspects of labour law and social welfare law. Another example could be the masculinity versus femininity dimension as a selection criterion to compare countries for maternity leave differences. A third possible connection between a cultural dimension and the law could be the (already mentioned) relationship between the score on the individualism index (IVD) and the right to respect for privacy. It is argued that the difference between individualistic or collectivistic societies is responsible for the value that is attached to privacy in different societies (Hofstede et al. 2011, pp. 134, 138).

11 It would be possible to test several assumptions quantitatively, with information available from Empirical Comparative Law. There is a large body of empirical law \& finance literature (see Spamann 2015 for an overview). The same holds true for empirical political science (see for example Easton's groundbreaking tetralogy from the 1950s and 1960s). One of my follow-up ideas of using cultural values as selection criteria, is searching for relations between culture and constitutions. Therefore, I'm building a dataset with cultural values - such as Hofstede's but also Fearon (2003), Alesina et al. (2003) and Schwartz (2006) - and constitutional statistics, such as Law \& Versteeg's (2011) analyses of constitutional comprehensiveness and ideology and data from the Comparative Constitutions Project. A first (provisional) analysis between number of rights (DV) in a constitution (source: Elkins, Ginsburg, and Melton, Comparative Constitutions Project dataset) and (a) uncertainty avoidance and (b) legal origin (French, Common, German, Scandinavian, Portuguese, Socialist and Islamic) shows the following results: a. There was a positive correlation between the two variables $[r=0,307, n=100, p=0,002$ (twotailed)]: a higher score on uncertainty avoidance is related to more human rights in constitutions. b. There was a significant effect of legal origin on number of rights at the $\mathrm{p}<.05$ level for the seven conditions $[\mathrm{F}(6,76)=3,506, \mathrm{p}=0,004]$, with less rights in Scandinavian (mean=36,4), Islamic $(37,4)$ and Common $(39,45)$ systems. In comparison, the mean in countries with a French system is a number of rights of 57,29 . (This, of course, explains nothing about the actual human rights protection.) 
Figure 1. Comparison of the Dutch culture with the culture of the United Kingdom on all six dimensions.

\author{
Netherlands \\ in comparison with United Kingdom
}

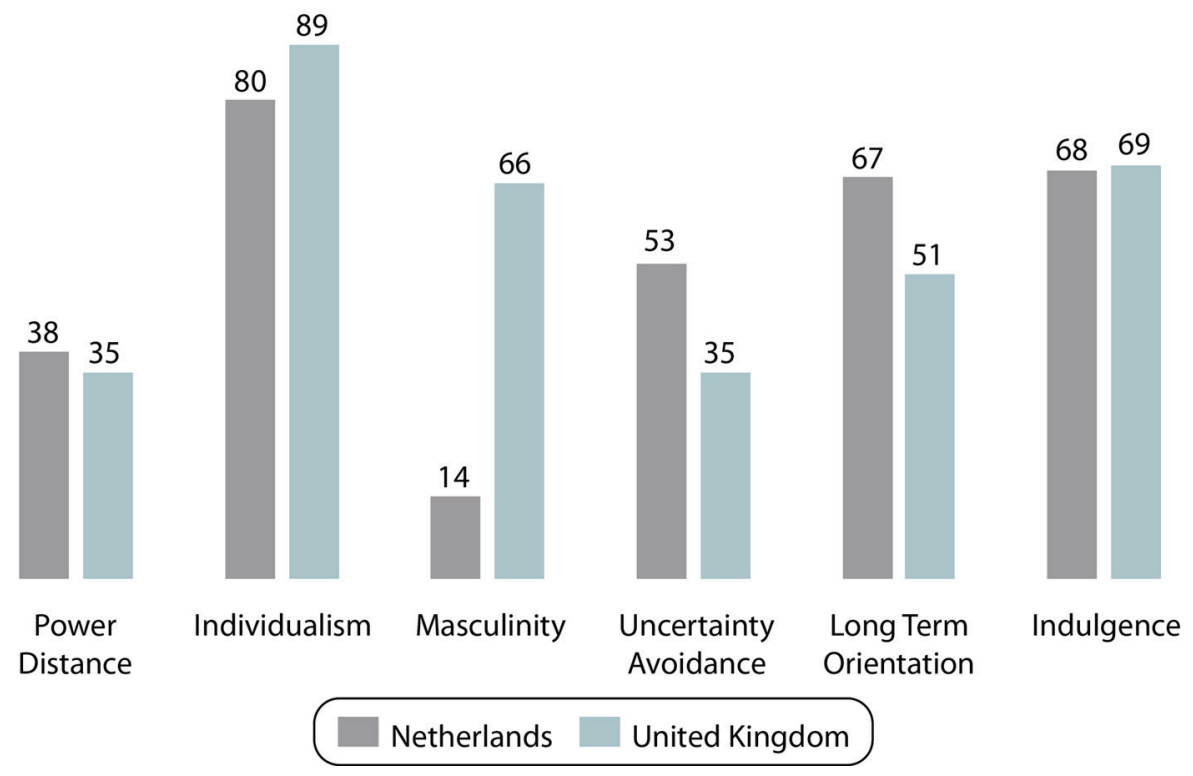

Note: https://geert-hofstede.com/netherlands.html, comparison made on 27 April 2017.

In individualistic cultures, ' $\mathrm{I}$ ' is more important than the 'we-group' and the reasoning is that therefore more attention is paid to privacy in countries with a high IVD score. Anglo-Saxon, North- and Northwest-European countries score high on IVD, and countries in South and Central America, East and Southeast Asia, the Middle East and Africa score low on the IVD (and therefore high on collectivism). It is therefore no wonder that the already mentioned comparison of Blok between the United States of America (no. 1 on the IVD in 2011) and the Netherlands (no. 4 on the IVD in 2011) led to the conclusion that especially the similarities in privacy law were prominent. A comparison among, for example, the United States of America (IVD of $91^{12}$ ), the Netherlands (IVD of 80 (see Figure 1)), Japan (IVD of $46^{13}$ ), Russia (IVD of $39^{14}$ ) and Guatemala (IVD of $6^{15}$ ) would provide a basis to assess whether privacy laws around the world share a common core, while the case selection includes countries with different IDV scores. 


\subsection{Privacy and Culture}

As mentioned before, it has been hypothesized by Hofstede and legal scholars that the concept of privacy, and therefore also privacy laws, is dependent on culture. On the basis of the above-described cultural-psychological research, Hofstede and colleagues argued that the difference between individualistic and collectivistic societies is responsible for the value that is attached to privacy in different societies (Hofstede et al. 2011, pp. 134, 138). It is usual to relate privacy to (or maybe even identify it with) individualism as a cultural dimension. However, most comparative research has been done with countries that score (relatively) high on the IDV and/or North American and European countries, ${ }^{16}$ and it could be that an IDV case selection will lead to other conclusions. Looking at the concept of privacy from a cultural point of view is then necessary to assess whether privacy is a universal phenomenon and in which form, or whether it is only meaningful for certain ethnic, cultural and/or social groups.

What is striking about the hypothesis of Hofstede and colleagues - that privacy is valued more in individualistic societies (Hofstede et al. 2011, pp. 134, 138) - is that the concept of 'privacy' is not defined. The question that therefore arises is what concept of privacy is meant. Do people in individualistic societies put more or less importance on confidentiality of information or on living life in seclusion? Or could Whitman's distinction (Whitman 2003-2004, pp. 1160, 1208), between privacy-as-liberty and privacy-as dignity (cf. Boustein 1977-1978), be used to analyse individualistic and collectivistic countries' privacy laws? How do Koops and colleagues' eight privacy categories relate to culture (Koops et al. 20162017, p. 484)? Their typology includes four types of privacy-as-liberty (emphasis on freedom from) and four types of privacy-as-dignity (emphasis on freedom to). In addition, while a definition or typology of privacy is missing in Hofstede's research on the cultural dependency of privacy, legal researchers do not use cultural dimensions in a structured way in formulating hypotheses, selecting cases, and assessing and analysing privacy laws. Although not the main issue of this article, in the following I will briefly explore some of the differences between countries with diverse IDV scores, with a focus on the 'traditional' collectivistic countries Japan and Russia.

In general, privacy is also valued in collectivistic societies, but the emphasis is different from that in individualistic societies. Japanese society values anonymous personal expressions (Adams et al. 2011; Farrall 2012. and safeguarding personal information from outsiders (the 'out-group'), while that information is properly shared with the 'we-group' (Adams et al. 2009, pp. 332-334). Translated to a privacy typology: it could be that Japan (and other Eastern Asian countries with a similar IDV) value privacy-as-secrecy (for example, Gavison 1980, p. 428),

Whitman's transatlantic comparison of the concept of privacy between the United States of America on the one hand and Germany and France on the other, Blok's comparison between the United States of America and the Netherlands. Koops' et al. (2016-2017) also included the same transatlantic comparison and some Eastern European countries. 
privacy-as-information-control (for example, Tavani 2007, pp. 1-22). or privacyas-limited-access (for example, Moor 1997, p. 3). These typologies all incorporate, in one form or another, that a person can hold information about the self a secret or has the space to choose with whom personal information is shared.

For example, compared to English students a large majority of Japanese students tend to use a nickname on the internet. In addition, personal information that can be used to determine the identity of the Internet-user (such as study, work, date of birth) is rarely published (Adams et al. 2011). There are two distinct forms of communication in Japan, namely truth (honne) and 'sales talk' (tatemae) (Furuoka \& Kato 2008, and Adams et al. 2009, p. 332). With the 'in-group' (the group one identifies with), the truth is shared, while with the 'out-group' (strangers, outsiders) sales talk is communicated. The clear distinction between the 'in-group' and 'out-group' is one of the causes for the lower individualism score of Japan. This means that in collectivistic Japan considerable weight is attached to privacy, in the sense that some information is shared only with the 'in-group' and that the true identity on the internet is hidden.

The Constitution of Japan ${ }^{17}$ also shows the more collectivistic nature of Japan: for example, that the Emperor shall be a symbol for the unity of the People (Article 1), and that there is a chapter on Duties of the People. The word 'privacy' and the phrase 'personal life' do not exist in the Japanese Constitution, but it acknowledges aspects of privacy. Article 13 holds that 'All of the People shall be respected as individuals' and Article 22 holds that the People are free to choose any occupation to the extent that it does not interfere with the public welfare: which could mean that individuals can choose their personal and work life on the basis of their own personal preferences and personality. Article 35 offers a stereotypical privacy-as-liberty right (Whitman 2003-2004, p. 1212): the People are protected against unwarranted entries, search and seizures.

A Russian example of the value of privacy comes from classical literature: a scene from Dostoevsky's Crime \& Punishment. It is a discussion between Lebeziatnikov and Luzhin in which the first explains 'progressive ideas'. Lebeziatnikov discusses the question of whether members of the progressive community have the right to enter a room or home of another member of the progressive community at any time and concludes that this is the case. Luzhin points out that the entering can take place at an inopportune time at which Lebeziatnikov responds with: 'How vexed I am that when I was expounding our system I referred prematurely to the question of personal privacy! It's always a stumbling-block to people like you' (Dostoevsky 2000, p. 313). So, in the second half of the 19th century, personal privacy, in this specific example in the form of the protection against unwanted home invasion, was apparently a well-known concept in collectivistic ${ }^{18}$ Russia. $^{19}$

17 See http://japan.kantei.go.jp/constitution_and_government_of_japan/constitution_e.html, for an official translation. Last retrieved on 30 May 2017.

18 Russia is listed as number 39 out of 76 countries on the IDV index. Hofstede et al. 2011, p. 105.

19 Chapman argues that 'the origins of Russian collectivism can be seen even from prehistoric times'. Chapman 1998, pp. 12-14. 
The Russian Constitution ${ }^{20}$ acknowledges the right to respect for privacy in a more explicit way than the Japanese Constitution: Article 23 (1) holds that 'Everyone shall have the right to the inviolability of private life, personal and family secrets, the protection of honour and good name.' The Russian Constitution also recognizes the inviolability of the home (Article 25) and of correspondence (Article 24), except for the cases established by federal law or by a court's decision. Of course, it is unclear how the Russian State and the State officials behave in practice and how the law in action works - the amount of Article 8 ECHR complaints submitted by the ECtHR does not offer a positive perspective - but it is clear that the Russian Constitution acknowledges aspects of privacy (at least in the form of 'window dressing' for the international arena). The addition of the inviolability of secrets and the protection of honour and a good name can been interpreted as an emphasis on privacy-as-secrecy, privacy-as-information-control or privacy-aslimited-access as well. In comparison, the ECtHR tends to emphasize on privacyas-liberty, i.e. the freedom to determine one's own (quality of) life based on notions such as 'personal identity' ${ }^{21}$ and 'personal development'. ${ }^{22}$

In addition, Westin argues on the basis of many examples of primitive cultures that they value privacy too (also Westin 1988, pp. 61-70). He analysed different aspects of privacy, including social cohesion, intimacy and exclusivity that play a role in regions such as Eastern Bolivia, Bali and Java and the Tuareg tribe in North Africa. However, the Guatemalan ${ }^{23}$ Constitution ${ }^{24}$ does not use the word 'privacy' or the phrase 'personal life', but Article 2 states that it is the State's duty to guarantee the 'life, liberty, justice, security, peace, and the integral development of the person'.

So, it is short-sighted to conclude, as Hofstede did, that privacy is less important in collectivistic societies just because they attach more importance to strong and close (family) ties and less importance to 'the self'. The (already mentioned) assumption of Blok - that he expected significant differences between the content of the right to privacy in the Dutch and American law because of cultural differences between the two countries - is also short-sighed. Hofstede didn't use a clearly defined concept of privacy, and Blok overlooks the cultural similarities between the Netherlands and the United States. In order to determine the cultural dependence of privacy, a more precise analysis of the concept of privacy is required. In addition, a more solid case selection based on cultural differences,

20 See http://www.constitution.ru/en/10003000-03.htm, for an official translation. Last retrieved on 30 May 2017.

21 See for example ECtHR (GC) 11 July2002, Appl. No. 28957/95, para. 90 (Christine Goodwin v. The United Kingdom); ECtHR (GC) 15 March 2012, Appl. Nos. 4149/04 \& 41029/04, para. 58 (Aksu v. Turkey).

22 See for example ECtHR 6 February 2001, Appl. No. 44599/98, para. 47 (Bensaid v. The United Kingdom); ECtHR 12 June 2003, Appl. No. 35968/97, para. 69 (Van Kuck v. Germany); ECtHR 12 January 2010, Appl. No. 4158/05, para. 61 (Gillan \& Quinton v. The United Kingdom), ECtHR 17 July 2012, Appl. No. 2913/06, para. 78 (Munjaz v. The United Kingdom).

24 See http://www.right2info.org/resources/publications/laws-1/guatemala_constitution_eng, for a translation. Last retrieved on 30 May 2017. 
especially the IDV, can certainly take the theorizing of the universal concept of privacy forward.

\section{Conclusion}

A sound methodology is the cornerstone of research. Explaining the methodology in detail helps others to understand why research is conducted in a particular way, and forms the basis for understanding the significance of the project. Although the method of comparative law is used widely, the methodological aspect of comparative law remains undertheorized. This is especially true for the choice of case selection criteria. Hofstede's cultural dimensions can be a major asset as case selection criteria. The dimensions are supported, reproduced and refined by decades of research, and Hofstede's theory is one of the most robust psychological theories of the last century. Countries can be quickly categorized on different aspects of culture and the application of Hofstede's criteria could identify aspects of culture that are more or less influential on certain fields of the law in certain respects. This way, Hofstede's theory can help find and explain which (aspect of the) law(s) are an expression of culture. ${ }^{25}$ In this way, the comparative research will use cultural differences between countries to (1) formulate hypotheses about legal differences; (2) select cases on the basis of the cultural-psychological dimensions, which act as independent variables; and (3) explain legal differences.

\section{References}

Adams, A.A., Murata, K., \& Orito, Y. (2009). The Japanese sense of information privacy. AI \& Soc, 4: 327-341.

Adams, A.A., Murata, K., Orito, Y., \& Parslow, P. (2011). Emerging social norms in the UK and Japan on privacy and revelation in SNS. IRIE, 12: 18-26.

Ailon, G. (2008). Mirror, mirror on the wall: culture's consequences in a value test of its own design. The Academy of Management Review, 33(4): 885-904.

Alesina, A.A., Easterly, W., Devleeschauwer, A., Kurlat, S. \& Wacziarg, R.T. (2003). Fractionalization. Journal of Economic Growth, 8(2): 155-194.

Baskerville, F.R. (2003). Hofstede never studied culture. Accounting, Organizations and Society, 28: 1-14.

Blok, P.H. (2002). Het recht op privacy: een onderzoek naar de betekenis van het begrip 'privacy' in het Nederlandse en Amerikaanse recht (diss. Tilburg). Den Haag: Boom Juridische uitgevers.

Boustein, E.J. (1977-1978) Privacy is dear at any price: a response to professor Posner's economic theory. Ga. L. Rev., 12(2): 429-453.

Chapman, S.R. (1998) Collectivism in the Russian world view and its implications for Christian ministry. East-West Church and Ministry Report, 4: 12-14.

25 It also works the other way around. If no relations between cultural values and a nation legal aspects can be found, what does that teach us about Hofstede's cultural theory? 
Di Robilant, A. (2016). A symposium on Ran Hirschl's comparative matters: the renaissance of comparative constitutional law: big questions comparative law. B.U. L. Rev. 96(4): 1325-1345.

Dixon, R., \& Ginsburg, T. (2015) (Eds.), Comparative constitutional law in Asia. Northampton: MA: Edward Elgar Publishing.

Dostoevsky, F. (2000). (trans. C. Garnett). Crime and punishment. Woodsworth Classics.

Fang, T. (2003). A critique of Hofstede's fifth national culture dimension. International Journal of Cross-Cultural Management, 3(3): 347-368.

Farrall, K. (2012). Online collectivism, individualism and anonymity in East Asia. Surveillance \& Society, 9(4): 424-440.

Fearon, J.D. (2003). Ethnic and Cultural Diversity by Country. Journal of Economic Growth, 8(2): 195-222.

Furuoka, F., \& Kato, I. (2008). The 'Honne-Tatemae' dimension in Japan's foreign aid policy. Electronic Journal of Contemporary Japanese Studies, 6, http://www. japanesestudies.org.uk/articles/2008/FuruokaKato.html (last retrieved on 22 October 2017).

Gavison, R. (1980). Privacy and the limits of law. The Yale Law Journal, 89(3): 421-471.

Hage, J. (2014). Comparative law as method and the method of comparative law. Maastricht European Private Law Institute Working Paper, 11: 2-14.

Hirschl, R. (2005). The question of case selection in comparative constitutional law. The American Journal of Comparative Law, 53(1): 125-155.

Hirschl, R. (2011). The Nordic counternarrative: democracy, human development, and judicial review. I. CON, 9(2): 449-469.

Hirschl, R. (2014). Comparative matters. Oxford: Oxford University Press.

Hirschl, R. (2016). Comparative Matters: Response to Interlocutors. B.U. L. Rev., 96(4): 1393-1424

Hofstede, G. (1997). Uncommon sense about organizations: cases, studies and field observations. New York: NY: McGraw-Hill.

Hofstede, G. (2001). Culture's consequences: comparing values, behaviors, institutions and organizations across nations (2nd edn). Thousand Oaks, CA: Sage Publications.

Hofstede, G., \& Hofstede, G.J. (2005). Cultures and organizations: software of the mind. McGraw Hill.

Hofstede, G., Hofstede, G.J., \& Minkov, M. (2010). Cultures and organizations: software of the mind (3rd edn). McGraw-Hill.

Hofstede, G., Hofstede, G.J., \& Minkov, M. (2011). Allemaal andersdenkenden: Omgaan met cultuurverschillen. Amsterdam: Contact.

Hofstede, G.H. (1980). Culture's consequences: international differences in work-related values. Beverly Hills: CA: Sage.

Hofstede, G.H. (1984). Culture's consequences: comparing values, behaviors, institutions, and organizations across nations. Thousand Oaks: CA: Sage.

Hofstede, G.J., Pederson, P.B., \& Hofstede, G. (2002). Exploring culture: exercises, stories and synthetic cultures. Yarmouth: MA: Intercultural Press.

Huxley, A. (1997). Review of 'The Golden Yoke: The Legal Cosmology of Buddhist Tibet by Rebecca Redwood French; Law and Morality in Ancient China: The Silk Manuscripts of Huang-Lao by R. P. Peerenboom'. The Yale Law Journal, 106(6): 1885-1951.

Jackson, V.C. (2016). Comparative constitutional law, legal realism, and empirical legal science. Boston University Law Review, 96(4): 1359-1374.

Kirkman, B.L., Lowe, K.B., \& Gibson, C.B. (2006). A quarter century of culture's consequences: a review of empirical research incorporating Hofstede's cultural values framework. Journal of International Business Studies, 37(3): 285-320. 
Kitagawa, Z. (2006). Development of comparative law in East Asia. In M. Reimann, \& R. Zimmermann (Eds.), The Oxford Handbook of Comparative Law (pp. 237-260). Oxford: Oxford University Press.

Koops, B-J., Newell, B., Timan, T., Skorvanek, I., Chokrevski, T., \& Galic, M. (2016-2017). A typology of privacy. U. Pa. J. Int'l L., 38(2): 483-575.

Law, D.S., \& Versteeg, M. (2011). The evolution and ideology of global constitutionalism. California Law Review, 99(5): 1163-1258.

McSweeney, B. (2008). Hofstede's model of national cultural differences and their consequences: a triumph of faith - a failure of analysis. Human Relations, 55(1): 89-117.

Meuwese, A. (2006). Comment on Hirschl's 'The Question of Case Selection in Comparative Constitutional Law'. ComparativeLawBlog: http://comparativelawblog. blogspot.com/2006/08/anne-meuweses-comment-on-hirschls.html (last retrieved on 22 October 2017).

Moor, J.H. (1997). Towards a theory of privacy in the information age. Computers and Society, 27(3): 27-32.

Palmer, V.V. (2005). From Lerotholi to Lando: some examples of comparative law methodology. The American Journal of Comparative Law, 53(1): 261-290.

Schwartz, S.H. (2006). A Theory of Cultural Value Orientations: Explication and Applications. Comparative Sociology, 5 (2-3): 137-182.

Siems, M. (2014). Comparative law. Cambridge: Cambridge University Press.

Spamann H. (2015). Empirical Comparative Law. Annual Review of Law and Social Science, 11: 131-153.

Tavani, H.T. (2007). Philosophical theories of privacy: implications for an adequate online privacy policy. Metaphilosophy, 1: 1-22.

van Boom, W., \& van Gestel, R. (2015). Rechtswetenschappelijk onderzoek. Uitkomsten van een landelijke enquête. NJB, 20: 1336-1347.

van Hoecke, M. (2015). Methodology of comparative legal research. Law \& Method. doi: 10.5553/REM/.000010.

Westin, A.F. (1988). The origins of modern claims to privacy. In F.D. Schoeman (Ed.), Philosophical dimensions of privacy: an anthology (pp. 56-74). Cambridge: Cambridge University Press.

Whitman, J.Q. (2003-2004). The two western cultures of privacy: dignity versus liberty. Yale L.J., 113: 1151-1221.

$\mathrm{Wu}, \mathrm{Y}$. (2016). Hofstede's cultural dimensions 30 years later: a study of Taiwan and the United States. Intercultural Communication Studies, XV: 1: 33-42.

Young, K.G. (2016). On what matters in comparative constitutional law: a comment on Hirschl. B.U. L. Rev., 96(4): 1375-1392. 